\title{
Evaluation of toxicological risk of foodstuffs contaminated with heavy metals in Swat, Pakistan
}

\author{
Kifayatullah Khan ${ }^{\text {a,b,c }}$, Hizbullah Khan ${ }^{a}$, Yonglong Lu ${ }^{\text {b,* }}$, Ihsan Ihsanullah ${ }^{\text {d }}$, Javed Nawab ${ }^{\text {, }}$ \\ Sardar Khan ${ }^{\mathrm{a}}$, Noor S. Shah ${ }^{\mathrm{e}}$, Isha Shamshad ${ }^{\mathrm{a}}$, Afsheen Maryam ${ }^{\mathrm{a}}$ \\ a Department of Environmental Sciences, University of Peshawar, Peshawar 25120, Pakistan \\ ${ }^{\mathrm{b}}$ State Key Laboratory of Urban and Regional Ecology, Research Centre for Eco-environmental Sciences (RCEES), \\ Chinese Academy of Sciences (CAS), 18 Shuangqing Road, Beijing 100085, China \\ ${ }^{\mathrm{c}}$ Department of Environmental Sciences, University of Swat, Swat 19130, Pakistan \\ ${ }^{\mathrm{d}}$ Nuclear Institute for Food and Agriculture (NIFA), Tarnab, Peshawar, Pakistan \\ e Institute of Chemical Sciences, University of Swat, Swat 19130, Pakistan
}

\section{A R T I C L E I N F O}

\section{Article history:}

Received 15 February 2014

Received in revised form

14 May 2014

Accepted 15 May 2014

Available online 2 August 2014

\section{Keywords:}

Bioaccumulation

Foodstuffs

Health risks

Heavy metals

Ingestion

Pakistan

\begin{abstract}
A B S T R A C T
This study aimed to assess the concentrations of heavy metals such as cadmium (Cd), chromium (Cr), copper $(\mathrm{Cu})$, manganese $(\mathrm{Mn})$, nickel $(\mathrm{Ni})$, lead $(\mathrm{Pb})$ and zinc $(\mathrm{Zn})$ in the available foodstuffs (crops, milk and water), their bioaccumulation in human body and potential human health risks in Swat valley, northern Pakistan. Heavy metal concentrations in foodstuffs and human blood (adults (18-above) and children (1-12 years)) were analyzed using atomic absorption spectrometer. The results revealed high level of $\mathrm{Mn}$ in foodstuffs followed by $\mathrm{Cr}>\mathrm{Cu}>\mathrm{Zn}>\mathrm{Ni}>\mathrm{Cd}>\mathrm{Pb}$, which significantly increased the levels of heavy metals in the adult's blood as compared to that of children in the order of $\mathrm{Cr}>$ $\mathrm{Zn}>\mathrm{Mn}>\mathrm{Ni}>\mathrm{Pb}>\mathrm{Cu}>\mathrm{Cd}$. Principal component analysis showed that selected foodstuffs were the possible sources of metal contamination in human blood, while correlation analysis revealed that the concentrations of $\mathrm{Cr}, \mathrm{Cu}, \mathrm{Mn}, \mathrm{Ni}, \mathrm{Pb}$ and $\mathrm{Zn}$ in foodstuffs significantly correlated with that in human blood. Moreover, risk assessments for individual metals via foodstuffs were found within safe limits, except for $\mathrm{Cd}(\mathrm{HQ}>1)$; Whereas, for aggregate multiple metals the risk was calculated as $3.97 \mathrm{E}+00$ $(\mathrm{HI}>1)$, in which water and milk were perceived as the greater contributors (81 percent) to $\mathrm{HI}$; while fruits, grains and vegetables contributed 5 percent each, and pulses 4 percent.
\end{abstract}

(c) 2014 Elsevier Inc. All rights reserved.

\section{Introduction}

Pollution of heavy metals such as $\mathrm{Cd}, \mathrm{Cr}, \mathrm{Cu}, \mathrm{Mn}, \mathrm{Ni}, \mathrm{Pb}$ and $\mathrm{Zn}$ in foodstuffs including food crops, milk and water is one of the detrimental health issues in the world due to their nonbiodegradable and persistent nature (Sekomo et al., 2011; Ali and Malik, 2011; Donaldson et al., 2010). The dietary intake of metals through contaminated foodstuffs is the main route of exposure to heavy metals for human beings, which can cause serious health hazards (Amin et al., 2013; Rahman et al., 2014). Usually, human beings are exposed to metals at trace levels either voluntarily through supplementation or involuntarily through intake of contaminated foodstuffs (Farid et al., 2004). Through

\footnotetext{
Abbreviations: ANOVA, analysis of variance; CAS, Chinese Academy of Sciences; CDI, chronic daily intake; HI, hazard index; HQ hazard quotient; PCA, principle component analysis; RfD, oral reference dose; TWAS, The World Academy of Sciences

* Corresponding author. Fax: +86 1062918177.

E-mail address: yllu@rcees.ac.cn (Y. Lu).
}

food ingestion nutrients and trace metals are assimilated into blood which acts as a transport medium to and from the tissues; and provides rapid and reliable information about the heavy metal metabolism in living body (Pasha et al., 2010). The level of metals in blood depends on the bio-accessibility rate and is considered as an index of biologically active metals in the body reflecting the environmental exposure of a population (Jan et al., 2011).

Heavy metals i.e. $\mathrm{Cd}, \mathrm{Cr}, \mathrm{Ni}$ and $\mathrm{Pb}$ are very toxic contaminants, their excessive bioaccumulation can cause profound biochemical changes inside living bodies and produce both chronic and acute health consequences, including kidney dysfunction, polycythemia, bone fracture, respiratory illness, memory deterioration, asthma, heart problems and various kind of cancers (Fischer et al., 2003; Kavcar et al., 2009; Khan et al., 2010; Mijal and Holzman, 2010; Zhao et al., 2012; Er et al., 2013).

Whereas, metals i.e. $\mathrm{Cu}, \mathrm{Mn}$ and $\mathrm{Zn}$ are essentially required for body growth and functions, they may be harmful above certain levels (Huang et al., 2008; Amin et al., 2013; Hu et al., 2013; Rahman et al., 2014). Cu is a redox-active metal and can cycle between its oxidized cupric $\left(\mathrm{Cu}^{2+}\right)$ and reduced cuprous $\left(\mathrm{Cu}^{+}\right)$ 


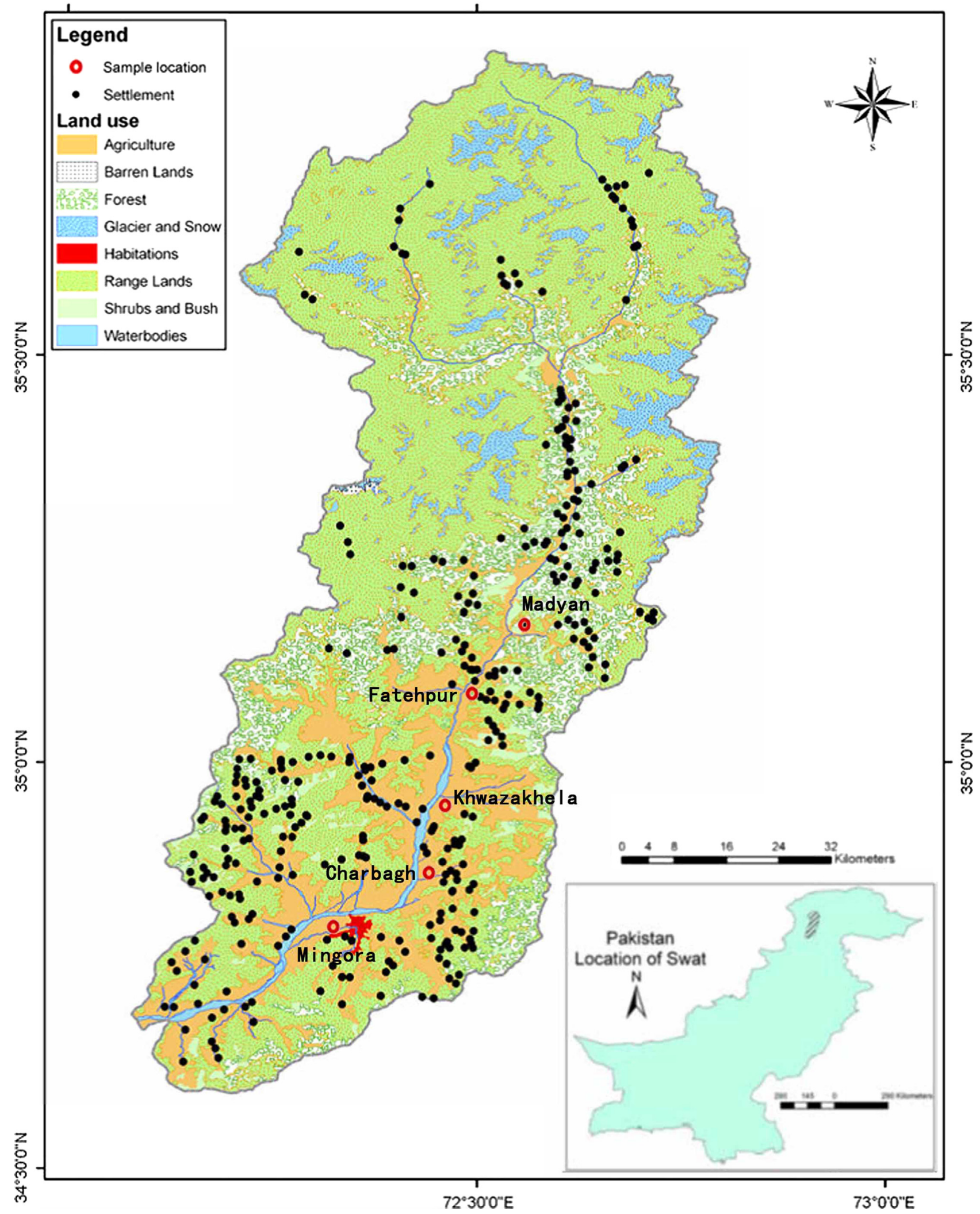

Fig. 1. Location map of the study area showing the sampling sites and different land-use classification in Swat valley, northern, Pakistan.

forms. Its excessive intracellular accumulation can induce growth proliferation, cancer and neurological diseases, while its deficiency can lead to normocytic, hypochromic anemia, leukopenia and neutropenia (Pasha et al., 2010). Similarly, Mn is essentially required as a co-factor for arginase enzyme in liver, pyruvate carboxylase enzyme in gluconeogenesis and astrocyte and glutamine enzymes in brain, but over exposure to Mn can cause permanent neurodegenerative damage (Bocca et al., 2011). While, 
sufficient amount of $\mathrm{Zn}$ is essentially required in the production of more than 300 different enzymes. However, its excessive exposure can cause a sideroblasticanemia, while its deficiency can produce growth retardation, anorexia, delayed sexual maturation, mental retardation and immune dysfunction (Muhammad et al., 2011).

Therefore, to protect the public health and to ensure timely warning for possible accumulations, it is necessary to extend our knowledge about the heavy metal bioaccumulation in human blood via foodstuff consumption and their relation with environmental exposure. In the study area, heavy metal contaminations in drinking water (surface and groundwater) and agricultural crops such as fruits (apple, pear, persimmon and walnut), grains (maize, wheat and rice) and vegetables (pumpkin, potato, tomato, broad bean, bitter gourd, ladyfinger and onion) were assessed in our previous articles (Khan et al., 2013a, 2013b). To explore further the multiple human exposures to heavy metals and combined impacts, this paper aims to determine the overall contaminations of heavy metals in available foodstuffs (e.g., fruits, grains, pulses, vegetables, milk and water), their bioaccumulation in human blood and potential human health risks in Swat valley, northern Pakistan.

\section{Materials and methods}

\subsection{Study area}

Swat valley (Fig. 1) is one of the largest valleys in Hindu Kush mountain system, north-west Pakistan, located between $34^{\circ} 34^{\prime}$ to $35^{\circ} 55^{\prime}$ north latitude and $71^{\circ} 10^{\prime}$ to $72^{\circ} 50^{\prime}$ east longitude with an altitude ranging from $733 \mathrm{~m}$ in the south to approximately $5740 \mathrm{~m}$ in the north (Rahman and Khan, 2011; Qasim et al., 2011). The overall weather of the region is affected by almost all the climatic factors such as latitude, altitude and rain bearing winds i.e. cyclone and monsoon winds. Agriculture is the dominant profession because of high fertile soil which is suitable for growth of wheat and maize as major crops along with different fruits, grains, pulses and vegetables. Cattles such as buffalos and cows are generally raised as dairy animals for fresh milk and other dairy products, while River Swat, natural springs and wells are used as a source of water for domestic and agricultural purposes (Khan et al., 2013a).

\subsection{Sampling and pre-treatment}

All the samples were collected in the year 2010-2011 at five different locations in the study area along the downstream of Swat River. Locally harvested food crops such as fruits (apple, pear, persimmon and walnut), grains (maize, wheat and rice), pulses (chick pea, pigeon pea, white lentil, kidney bean and mung bean) and vegetables (pumpkin, potato, tomato, broad bean, bitter gourd, ladyfinger and onion) and water samples were collected in the study area and pre-treated in the laboratory as introduced in our previous papers (Khan et al., 2013a, 2013b).

Fresh milk samples (buffalo/cow) were collected in $100 \mathrm{ml}$ clean acid-washed polyethylene plastic bottles in the near local dairy farms of the five locations and stored at $4{ }^{\circ} \mathrm{C}$ prior to digestion for metals analysis. Whereas, human blood samples were collected under the local ethical committee approval from the same locations of the study area at the same time when the foodstuffs were collected. Before taking samples the respondents were divided into two age groups i.e. adults (18 years and above) and children (1-12 years); and were asked to complete a structured questionnaire containing socio-demographic conditions such as health status, medication, occupation, smoking habits, alcohol consumption and other lifestyles. Then the required blood samples were taken in clean polypropylene EDTA containing tubes by vein puncturing using disposable syringes and transported to the laboratory under ice-cold conditions.

\subsection{Extraction/digestion}

Food crops were digested through wet digestion method as introduced in our previous work (Khan et al., 2013a). Whereas, milk samples were digested according to Singh et al. (2010) method. Briefly, a known volume of milk sample (25 ml) was taken in beaker and heated gently without boiling to reduce the water content. After cooling the required samples were digested in $10 \mathrm{ml}$ of $\mathrm{HNO}_{3}$ and $5 \mathrm{ml}$ of $\mathrm{HClO}_{4}$ until a transparent solution was obtained. Moreover, the blood samples were extracted using Jan et al. (2011) method. Briefly, $3 \mathrm{ml}$ of blood sample was put into a conical flask and then $15 \mathrm{ml}$ of $\mathrm{HClO}_{4}$ and $\mathrm{HNO}_{3}$ in the ratio of $1: 4$ were added. They were kept overnight and then heated on hot plate at different standard temperatures until a transparent solution was obtained. After cooling the acquired extracts were filtered through Whatman no. 42 filter papers and diluted up to $100 \mathrm{ml}$ volume using highly purified de-ionized water.

\subsection{Heavy metal determination}

Analytical grade chemicals (Merck Darmstadt, Germany) were purchased for sample preparation and analysis. Standard solutions of selected metals were prepared by diluting their corresponding $1000 \mathrm{mg} / \mathrm{L}$ certified standard solutions (Fluka Kamica, Busch Switzerland). The blank reagents and standard reference materials (Fluka Kamica, Busch Switzerland) were used to verify the accuracy and precision of digestion procedure and subsequent analyses The concentrations of $\mathrm{Cd}$ $\mathrm{Cr}, \mathrm{Cu}, \mathrm{Mn}, \mathrm{Ni}, \mathrm{Pb}$, and $\mathrm{Zn}$ in the filtrate of digested samples were estimated using graphite furnace atomic absorption spectrometer (GFAAS AAS-700 Perkin Elmer USA). The instrument was calibrated using standard solution of respective heavy metals manually prepared from their stock solutions. The instrumental detection limits of $\mathrm{Cd}, \mathrm{Cr}, \mathrm{Cu}, \mathrm{Mn}, \mathrm{Ni}, \mathrm{Pb}$ and $\mathrm{Zn}$ were $0.0008,0.0030,0.0015,0.0015,0.0060$ 0.0150 and $0.0015 \mathrm{mg} / \mathrm{L}$, respectively (Table S1, Supplementary material).

\subsection{Quality control}

The blank reagents and standard reference materials such as Batch 1701-3, BCR no. 150 and Fluka Kamica, Busch Switzerland for human blood, milk and foodstuffs, respectively, were used to verify the accuracy and precision of the digestion procedure and subsequent analyses. Whereas in view of data quality assurance, each sample batch was analyzed in a triplicate under standard opt-ionizing conditions within the confidence limit of 95 percent. The validity of the method was further ascertained by cross method checks, spiked recovery and replicate analysis.

\subsection{Risk assessment}

Health risk evaluation indicators such as hazard quotient (HQ) and hazard index (HI) for individual and multiple heavy metals were calculated to assess the potential chronic risks in the study area.

\subsubsection{Health risk of individual metal}

The potential chronic risk for individual metals is expressed as hazard quotient (HQ) and it was calculated using Eq. (1) (Huang et al., 2008; Kavcar et al., 2009; Khan et al., 2013).

$\mathrm{HQ}=\mathrm{CDI} / \mathrm{RfD}$

where $\mathrm{RfD}$ represents the oral reference dose of $\mathrm{Cd}, \mathrm{Cr}, \mathrm{Cu}, \mathrm{Mn}, \mathrm{Ni}, \mathrm{Pb}$ and $\mathrm{Zn}$, as $5.0 \mathrm{E}-04,1.5,3.7 \mathrm{E}-02,1.4 \mathrm{E}-01,2.0 \mathrm{E}-02,3.6 \mathrm{E}-02$ and $3.0 \mathrm{E}-01 \mathrm{mg} / \mathrm{kg}$-day, respectively (Shah et al., 2012; Khan et al., 2013b). While, CDI (mg/kg-day) represents the average chronic daily intake of metal via foodstuffs consumption, it was calculated using Eq. (2) (Muhammad et al., 2011; Khan et al., 2013a, 2013b).

$\mathrm{CDI}=\mathrm{C} \times \mathrm{DI} / \mathrm{BW}$

where C, DI and BW represent the heavy metal concentrations in foodstuffs (for food crop $\mathrm{mg} / \mathrm{kg}$; for water and milk $\mathrm{mg} / \mathrm{L}$ ), average daily intake of foodstuffs and average body weight, respectively. The average daily intake rate of foodstuffs (water, milk and food crop) was assumed to be 2 L/day of water (US EPA, 2011), $0.45 \mathrm{~L} /$ day of milk (questioner based), $0.345 \mathrm{~kg}$ /day of crop for adult (Khan et al., 2008); and $1 \mathrm{~L} /$ day of water (US EPA, 2011), 0.75 L/day of milk (questioner based), $0.232 \mathrm{~kg} /$ day of crop for child (Khan et al., 2008). The conversion factor (0.085) was used to convert wet weight of food crops i.e. (fruits, grains and vegetables) to dry weight (Khan et al., 2013a), whereas the average adult and children body weights were assumed to be 73 and $32.7 \mathrm{~kg}$, respectively (Jan et al., 2010; Khan et al., 2013a).

\subsubsection{Health risk of multiple metals}

The total potential chronic risk for multiple metals is expressed as hazard index (HI) and it was calculated using Eq. (3) (Huang et al., 2008; Cao et al., 2010; Bermudez et al., 2011).

$\mathrm{HI}=\mathrm{HQ}_{\mathrm{Cd}}+\mathrm{HQ}_{\mathrm{Cr}}+\cdots+\mathrm{HQ}_{n}$

where $\mathrm{HI}$ is the aggregate hazard index and $\mathrm{HQ}_{\mathrm{Cd}}, \mathrm{HQ}_{\mathrm{Cr}}$ and $\mathrm{HQ}_{n}$ are the calculated HQs of $\mathrm{Cd}, \mathrm{Cr} \ldots n$ metal, respectively. An index more than one is presumed to be unsafe for human health (US EPA, 2005; Khan et al., 2013a).

\subsection{Statistical analysis}

The descriptive statistics i.e. graphics, means, ranges and standard deviations for selected parameters were calculated using Microsoft Excel version 2010; while the statistical univariate and multivariate analysis i.e. one-way analysis of variance (one-way ANOVA), correlation analysis and principle component analysis (PCA) were executed using Statistical Package for the Social Sciences version 17. 
Cd

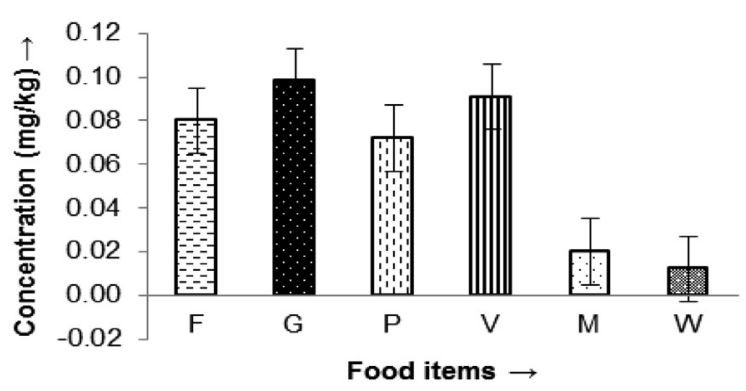

Cu

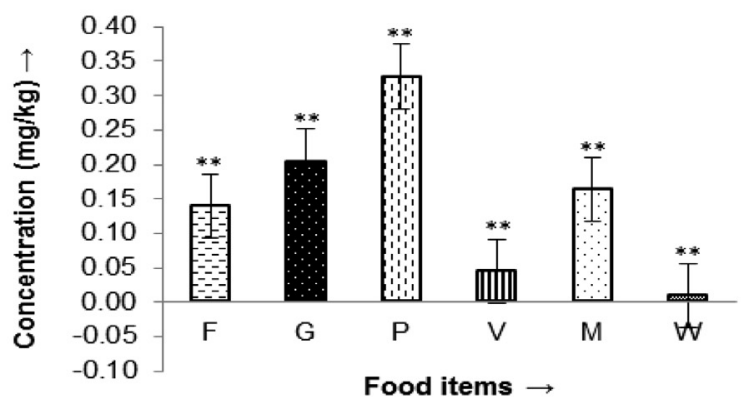

$\mathrm{Ni}$

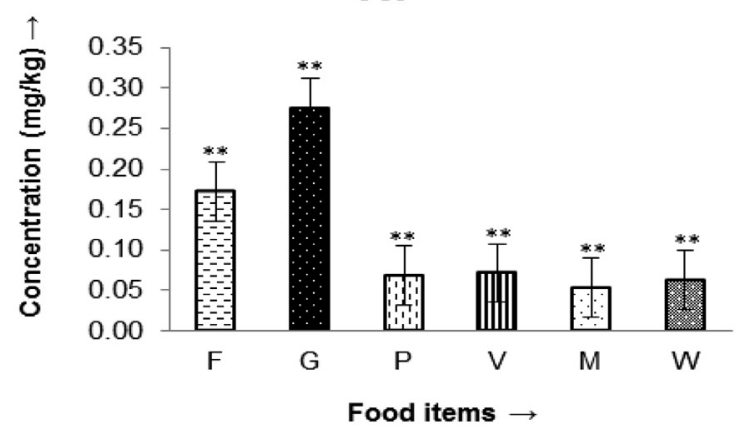

Zn

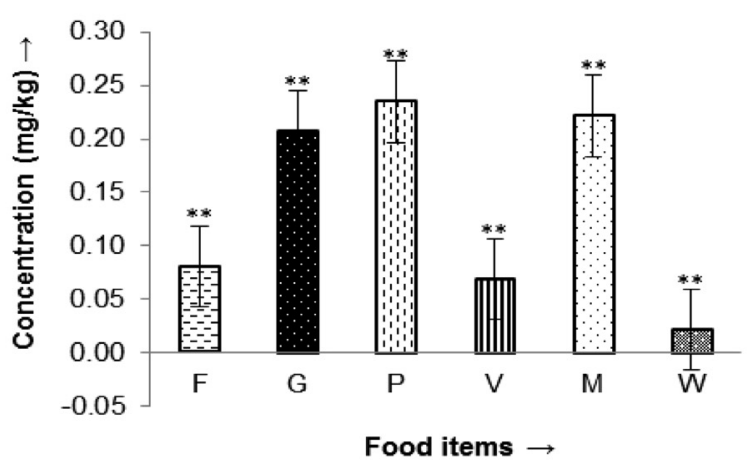

$\mathrm{Cr}$

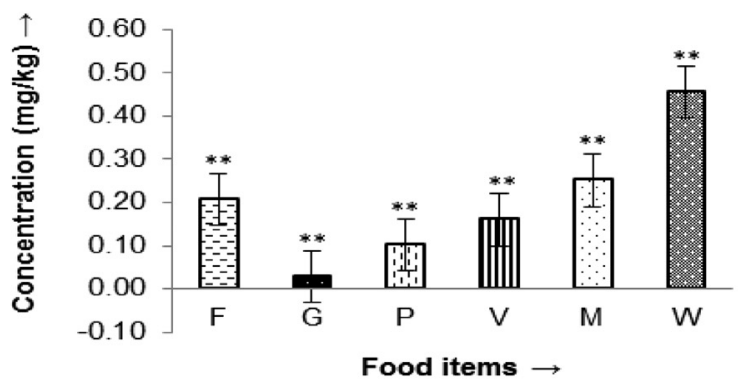

Mn

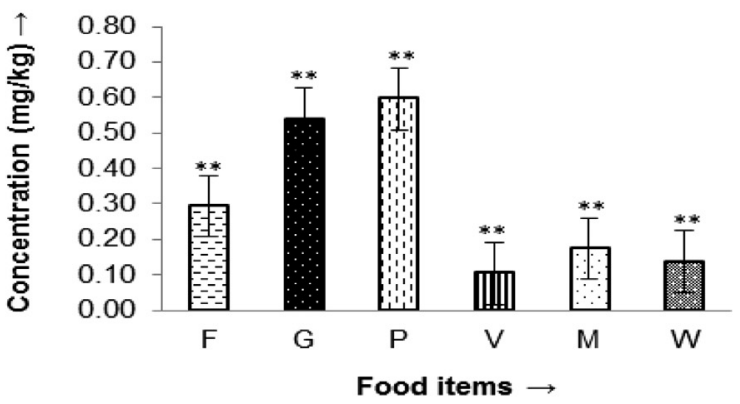

$\mathbf{P b}$

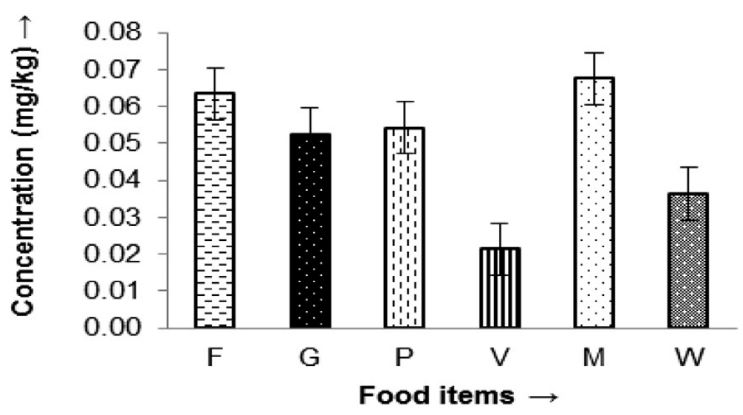

$\mathrm{F} \rightarrow \mathrm{Fruits}$

$\mathrm{G} \rightarrow \mathrm{Grains}$

$\mathrm{P} \rightarrow \mathrm{P}$ ulses

$\mathrm{V} \rightarrow \mathrm{V}$ eget a bles

$\mathrm{M} \rightarrow \mathrm{M}$ I I K

$\mathrm{W} \rightarrow \mathrm{W}$ at e r

$* * P \leq 0.01$

**Correlation is significant at the level of 0.01

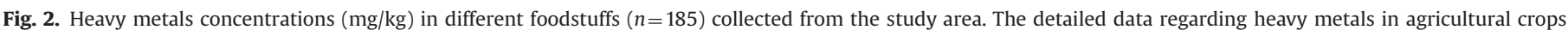

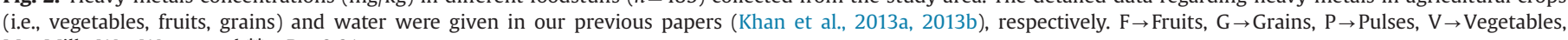
$\mathrm{M} \rightarrow$ Milk, $\mathrm{W} \rightarrow$ Water, and $* * \rightarrow \mathrm{P} \geq 0.01$. 


\section{Results and discussion}

\subsection{Levels of heavy metals in foodstuffs}

The mean concentrations of $\mathrm{Cd}, \mathrm{Cr}, \mathrm{Cu}, \mathrm{Mn}, \mathrm{Ni}, \mathrm{Pb}$ and $\mathrm{Zn}$ in foodstuffs collected in the study area were classified in terms of fruits, grains, pulses, vegetables, milk and water, and depicted in Fig. 2.

Statistically, heavy metal concentrations in foodstuffs were significantly varied $(p \leq 0.05)$. Moreover, Post hoc (Tukey test) demonstrated that, $\mathrm{Cr}, \mathrm{Cu}, \mathrm{Mn}, \mathrm{Ni}$ and $\mathrm{Zn}$ concentrations in selected foodstuffs were significantly $(p \leq 0.01)$ varied; while $\mathrm{Cd}$ and $\mathrm{Pb}$ showed no significant variation $(p>0.05)$ as shown in Fig. 2 . This variation in metal concentrations particularly in fruits, grains, pulses and vegetables from the study area may be credited to the differences in their morphology and physiology for uptake, exclusion, uptake/bioaccumulation and retention of heavy metals (Singh et al., 2010). The highest heavy metal concentration was noticed for Mn followed by $\mathrm{Cr}>\mathrm{Cu}>\mathrm{Zn}>\mathrm{Ni}>\mathrm{Cd}>\mathrm{Pb}$. Among these metals the concentrations of $\mathrm{Cd}, \mathrm{Cr}, \mathrm{Ni}$ and $\mathrm{Pb}$ were observed considerably higher than their safe limits as given in our previous studies (Khan et al., 2013a, 2013b). Besides, the concentrations of Mn in grains and pulses, $\mathrm{Cr}$ in water and milk, and $\mathrm{Ni}$ in grains and fruits were detected several folds higher than the rest of selected metals (Fig. 2).

The mean concentrations of $\mathrm{Cd}, \mathrm{Cr}, \mathrm{Cu}, \mathrm{Mn}, \mathrm{Ni}, \mathrm{Pb}$ and $\mathrm{Zn}$ in selected foodstuffs ranged from 0.012 to $0.098,0.028$ to 0.455 , 0.009 to $0.328,0.104$ to $0.596,0.053$ to $0.275,0.021$ to 0.068 and 0.022 to $0.235 \mathrm{mg} / \mathrm{kg}$, respectively, in the region (Fig. 2). The highest Cd mean concentration was observed in grain samples; while the lowest in water. This high concentration of $\mathrm{Cd}$ is due to high bioaccumulation of $\mathrm{Cd}$ in crops, which was also reported by Fytianos et al. (2001) and Chary et al. (2008). Similarly, Cr mean concentration was observed very high in water samples, compared with the results of the studies conducted by Muhammad et al. (2011) and Shah et al. (2012) in this country, which could be influenced by the geology as well as agricultural and industrial emissions in the area (Khan et al., 2013b). Cu and Mn are essentially required for body growth and functions, its mean variation in foodstuffs are given in Fig. 2. Ni concentration was recorded high in the grain samples, which was also reported by Huang et al. (2008) in Kunshan, China. Pb high level was noticed in milk samples; while its lower level in vegetables as portrayed in Fig. 2. The high concentration of $\mathrm{Pb}$ in the cattle's milk could be attributed to direct ingestion of fodder particularly water containing high levels of $\mathrm{Pb}$ in the area. Moreover, buffalo milk was found to have high concentrations of metals as compared to cow's milk which may be attributed to high fat content in buffalo's milk, which helps in metal retention due to the formation of bioactive (lipophilic) complexes (Jan et al., 2011). Zn concentrations in foodstuffs were also shown variation across the region; however, its highest mean concentration $(0.235 \mathrm{mg} / \mathrm{kg})$ was noticed in pulses; while the lowest $(0.022 \mathrm{mg} / \mathrm{kg}$ ) in water (Fig. 2).

Moreover, the detailed information on concentrations of selected heavy metals in different fruit, grain and vegetable species were given in our previous work (Khan et al., 2013a); and water contamination was specified by Khan et al. (2013b). The detailed statistics of heavy metals in pulses and milk samples are given in Tables 1 and S2 (Supplementary material) respectively.

\subsection{Bioaccumulation of heavy metals in human blood}

The basic statistical parameters of selected heavy metal concentrations in the human blood samples collected from five locations (Madyan, Fatehpur, Khwazakhela, Charbagh and Mingora) are summarized in Table 2. Statistically, a huge variation in the minimum, maximum and mean heavy metal concentrations was observed in the blood samples collected from five locations of the study area. The bioaccumulation of metals in blood of both adults and children were significantly varied ( $p \leq 0.01)$; whereas, $\mathrm{Cr}$ bioaccumulation was recorded relatively very high as compared to that of $\mathrm{Cd}, \mathrm{Cu}, \mathrm{Mn}, \mathrm{Ni}, \mathrm{Pb}$ and $\mathrm{Zn}$ as illustrated in Fig. S1 (Supplementary material).

According to Post hoc (Tukey test), Cd bioaccumulation in adult's blood showed significant variation $(p \leq 0.01)$ with $\mathrm{Cr}, \mathrm{Mn}$, $\mathrm{Ni}$ and $\mathrm{Zn}$; while in children's blood it was significantly varied $(p \leq 0.01)$ with $\mathrm{Cr}$, Mn and Zn (Fig. S1, Supplementary material). Similarly, $\mathrm{Cu}$ bioaccumulation in adult's blood showed significant variation $(p \leq 0.01)$ with $\mathrm{Cr}$, $\mathrm{Cu}$ and $\mathrm{Zn}$; while in children's blood it was significantly varied $(p \leq 0.01)$ with $\mathrm{Cr}$ and $\mathrm{Zn}$ only (Fig. S1, Supplementary material). Mn showed significant variation $(p \leq$ 0.01 ) with $\mathrm{Cd}, \mathrm{Cr}, \mathrm{Cu}$ and $\mathrm{Zn}$ in adults blood; while in children's blood it was significantly varied $(p \leq 0.01)$ with $\mathrm{Cd}, \mathrm{Cr}, \mathrm{Pb}$ and $\mathrm{Zn}$. $\mathrm{Ni}$ bioaccumulation in adults showed significant variation $(p \leq 0.01)$ with $\mathrm{Cd}, \mathrm{Cr}$ and $\mathrm{Zn}$; while in children's blood it was significantly varied $(p \leq 0.01)$ with $\mathrm{Cr}$ and $\mathrm{Zn}$ (Fig. S1, Supplementary material). $\mathrm{Pb}$ bioaccumulation in adults showed significant variation $(p \leq 0.01)$ with $\mathrm{Cr}$ and $\mathrm{Zn}$; while in children's blood it was significantly varied $(p \leq 0.01)$ with $\mathrm{Cr}$, Mn and $\mathrm{Zn}$ (Fig. S1, Supplementary material). Whereas, $\mathrm{Cr}$ and $\mathrm{Zn}$ bioaccumulation in both adults and children were significantly varied $(p \leq 0.01)$ with the rest of selected metals (Fig. S1, Supplementary material).

Table 1

Heavy metals concentrations $(\mathrm{mg} / \mathrm{kg})$ in foodstuffs $(n=55)$ collected from the study area.

\begin{tabular}{|c|c|c|c|c|c|c|c|c|}
\hline Foodstuffs & Statistics & Cd & $\mathbf{C r}$ & $\mathbf{C u}$ & Mn & $\mathrm{Ni}$ & $\mathbf{P b}$ & $\mathrm{Zn}$ \\
\hline \multicolumn{9}{|l|}{ Pulses $(n=25)$} \\
\hline \multirow[t]{2}{*}{ Cicer arietinum (chick pea) } & Range & $0.009-0.116$ & $0.044-0.142$ & $0.328-0.378$ & $0.757-0.980$ & $0.042-0.091$ & \multirow[t]{2}{*}{ BDL } & $0.211-0.304$ \\
\hline & Mean & $0.069 \pm 0.052$ & $0.090 \pm 0.038$ & $0.347 \pm 0.019$ & $0.894 \pm 0.083$ & $0.062 \pm 0.024$ & & $0.250 \pm 0.043$ \\
\hline \multirow[t]{2}{*}{ Cajanus cajan (pigeon pea) } & Range & $0.010-0.114$ & $0.055-0.136$ & $0.305-0.335$ & $0.413-0.758$ & $0.005-0.092$ & \multirow[t]{2}{*}{$\mathrm{BDL}$} & $0.169-0.239$ \\
\hline & Mean & $0.069 \pm 0.052$ & $0.096 \pm 0.034$ & $0.319 \pm 0.014$ & $0.539 \pm 0.164$ & $0.045 \pm 0.038$ & & $0.216 \pm 0.029$ \\
\hline \multirow[t]{2}{*}{ Vigna mungo (white lentil) } & Range & $0.015-0.116$ & $0.063-0.143$ & $0.308-0.371$ & $0.421-0.615$ & $0.016-0.093$ & \multirow[t]{2}{*}{ BDL } & $0.231-0.304$ \\
\hline & Mean & $0.072 \pm 0.052$ & $0.105 \pm 0.030$ & $0.329 \pm 0.026$ & $0.546 \pm 0.075$ & $0.050 \pm 0.030$ & & $0.266 \pm 0.032$ \\
\hline \multirow[t]{2}{*}{ Phaseolu svulgaris (kidney bean) } & Range & $0.011-0.127$ & $0.066-0.151$ & $0.330-0.355$ & $0.458-0.724$ & $0.038-0.053$ & $0.058-0.093$ & $0.183-0.260$ \\
\hline & Mean & $0.079 \pm 0.053$ & $0.106 \pm 0.033$ & $0.342 \pm 0.013$ & $0.603 \pm 0.108$ & $0.046 \pm 0.006$ & $0.077 \pm 0.018$ & $0.210 \pm 0.031$ \\
\hline \multirow[t]{2}{*}{ Vigna radiate (mung bean) } & Range & $0.006-0.126$ & $0.066-0.147$ & $0.020-0.435$ & $0.314-0.460$ & $0.021-0.512$ & $0.002-0.077$ & $0.178-0.314$ \\
\hline & Mean & $0.071 \pm 0.058$ & $0.110 \pm 0.032$ & $0.303 \pm 0.164$ & $0.400 \pm 0.056$ & $0.143 \pm 0.208$ & $0.040 \pm 0.053$ & $0.233 \pm 0.051$ \\
\hline \multicolumn{9}{|l|}{ Milk $(n=30)$} \\
\hline \multirow{2}{*}{ Fresh milk (buffalos/cows) } & Range & $0.014-0.031$ & $0.190-0.303$ & $0.001-0.589$ & $0.130-0.267$ & $0.006-0.200$ & $0.003-0.303$ & $0.112-0.389$ \\
\hline & Mean & $0.020 \pm 0.004$ & $0.251 \pm 0.032$ & $0.164 \pm 0.177$ & $0.174 \pm 0.043$ & $0.053 \pm 0.045$ & $0.068 \pm 0.063$ & $0.222 \pm 0.068$ \\
\hline
\end{tabular}

$n$, number of samples; \pm , standard deviation; BDL, below detection limits. 
Table 2

Heavy metals bioaccumulations $(\mathrm{mg} / \mathrm{L})$ in human blood $(n=200)$ collected from the study area.

\begin{tabular}{|c|c|c|c|c|c|c|c|}
\hline \multicolumn{3}{|c|}{ Parameters } & \multicolumn{5}{|l|}{ Sampling sites } \\
\hline Metal & Individual & Statistics & Madyan $(n=40)$ & Fatehpur $(n=40)$ & Khwazakhela $(n=40)$ & Charbagh $(n=40)$ & Mingora $(n=40)$ \\
\hline $\mathrm{Cd}$ & $\begin{array}{l}\text { Adults } \\
(n=20) \\
\text { Children } \\
(n=20)\end{array}$ & $\begin{array}{l}\text { Range } \\
\text { Mean } \\
\text { Range } \\
\text { Mean }\end{array}$ & $\begin{array}{l}0.011-0.020 \\
0.017 \pm 0.004 \\
0.012-0.021 \\
0.016 \pm 0.004\end{array}$ & $\begin{array}{l}0.014-0.020 \\
0.017 \pm 0.003 \\
0.011-0.020 \\
0.015 \pm 0.004\end{array}$ & $\begin{array}{l}0.013-0.020 \\
0.016 \pm 0.003 \\
0.012-0.021 \\
0.015 \pm 0.004\end{array}$ & $\begin{array}{l}0.010-0.018 \\
0.015 \pm 0.004 \\
0.011-0.019 \\
0.015 \pm 0.004\end{array}$ & $\begin{array}{l}0.014-0.022 \\
0.019 \pm 0.003 \\
0.014-0.020 \\
0.017 \pm 0.003\end{array}$ \\
\hline $\mathrm{Cr}$ & $\begin{array}{l}\text { Adults } \\
(n=20) \\
\text { Children } \\
(n=20)\end{array}$ & $\begin{array}{l}\text { Range } \\
\text { Mean } \\
\text { Range } \\
\text { Mean }\end{array}$ & $\begin{array}{l}0.629-0.651 \\
0.643 \pm 0.010 \\
0.624-0.651 \\
0.639 \pm 0.012\end{array}$ & $\begin{array}{l}0.644-0.654 \\
0.649 \pm 0.005 \\
0.647-0.655 \\
0.651 \pm 0.004\end{array}$ & $\begin{array}{l}0.662-0.670 \\
0.666 \pm 0.003 \\
0.648-0.659 \\
0.655 \pm 0.005\end{array}$ & $\begin{array}{l}0.673-0.679 \\
0.675 \pm 0.003 \\
0.671-0.680 \\
0.674 \pm 0.004\end{array}$ & $\begin{array}{l}0.683-0.686 \\
0.685 \pm 0.001 \\
0.678-0.684 \\
0.680 \pm 0.003\end{array}$ \\
\hline $\mathrm{Cu}$ & $\begin{array}{l}\text { Adults } \\
(n=20) \\
\text { Children } \\
(n=20)\end{array}$ & $\begin{array}{l}\text { Range } \\
\text { Mean } \\
\text { Range } \\
\text { Mean }\end{array}$ & $\begin{array}{l}0.052-0.061 \\
0.056 \pm 0.004 \\
0.053-0.062 \\
0.057 \pm 0.004\end{array}$ & $\begin{array}{l}0.046-0.057 \\
0.050 \pm 0.005 \\
0.049-0.062 \\
0.055 \pm 0.006\end{array}$ & $\begin{array}{l}0.055-0.072 \\
0.064 \pm 0.008 \\
0.054-0.057 \\
0.056 \pm 0.001\end{array}$ & $\begin{array}{l}0.017-0.065 \\
0.050 \pm 0.022 \\
0.060-0.063 \\
0.062 \pm 0.001\end{array}$ & $\begin{array}{l}0.005-0.015 \\
0.010 \pm 0.005 \\
0.006-0.379 \\
0.102 \pm 0.185\end{array}$ \\
\hline Mn & $\begin{array}{l}\text { Adults } \\
(n=20) \\
\text { Children } \\
(n=20)\end{array}$ & $\begin{array}{l}\text { Range } \\
\text { Mean } \\
\text { Range } \\
\text { Mean }\end{array}$ & $\begin{array}{l}0.159-0.162 \\
0.161 \pm 0.001 \\
0.152-0.158 \\
0.155 \pm 0.003\end{array}$ & $\begin{array}{l}0.155-0.167 \\
0.162 \pm 0.005 \\
0.152-0.164 \\
0.157 \pm 0.006\end{array}$ & $\begin{array}{l}0.163-0.171 \\
0.167 \pm 0.003 \\
0.162-0.173 \\
0.166 \pm 0.005\end{array}$ & $\begin{array}{l}0.158-0.165 \\
0.162 \pm 0.003 \\
0.158-0.165 \\
0.161 \pm 0.003\end{array}$ & $\begin{array}{l}0.147-0.173 \\
0.157 \pm 0.011 \\
0.147-0.244 \\
0.177 \pm 0.046\end{array}$ \\
\hline $\mathrm{Ni}$ & $\begin{array}{l}\text { Adults } \\
(n=20) \\
\text { Children } \\
(n=20)\end{array}$ & $\begin{array}{l}\text { Range } \\
\text { Mean } \\
\text { Range } \\
\text { Mean }\end{array}$ & $\begin{array}{l}0.040-0.094 \\
0.071 \pm 0.024 \\
0.026-0.068 \\
0.043 \pm 0.017\end{array}$ & $\begin{array}{l}0.050-0.089 \\
0.064 \pm 0.017 \\
0.045-0.114 \\
0.070 \pm 0.032\end{array}$ & $\begin{array}{l}0.075-0.179 \\
0.121 \pm 0.052 \\
0.054-0.165 \\
0.109 \pm 0.056\end{array}$ & $\begin{array}{l}0.180-0.286 \\
0.218 \pm 0.047 \\
0.104-0.199 \\
0.153 \pm 0.042\end{array}$ & $\begin{array}{c}0.113-0.311 \\
0.233 \pm 0.093 \\
0.099-0.386 \\
0.172 \pm 0.143\end{array}$ \\
\hline $\mathrm{Pb}$ & $\begin{array}{l}\text { Adults } \\
(n=20) \\
\text { Children } \\
(n=20)\end{array}$ & $\begin{array}{l}\text { Range } \\
\text { Mean } \\
\text { Range } \\
\text { Mean }\end{array}$ & $\begin{array}{l}0.006-0.044 \\
0.025 \pm 0.019 \\
0.006-0.034 \\
0.015 \pm 0.013\end{array}$ & $\begin{array}{l}0.033-0.035 \\
0.034 \pm 0.001 \\
0.048-0.092 \\
0.062 \pm 0.020\end{array}$ & $\begin{array}{l}0.099-0.105 \\
0.102 \pm 0.004 \\
0.009-0.054 \\
0.026 \pm 0.021\end{array}$ & $\begin{array}{l}0.020-0.075 \\
0.052 \pm 0.029 \\
0.036-0.090 \\
0.056 \pm 0.025\end{array}$ & $\begin{array}{l}0.007-0.107 \\
0.072 \pm 0.056 \\
0.002-0.009 \\
0.005 \pm 0.004\end{array}$ \\
\hline $\mathrm{Zn}$ & $\begin{array}{l}\text { Adults } \\
(n=20) \\
\text { Children } \\
(n=20)\end{array}$ & $\begin{array}{l}\text { Range } \\
\text { Mean } \\
\text { Range } \\
\text { Mean }\end{array}$ & $\begin{array}{l}0.527-0.807 \\
0.671 \pm 0.134 \\
0.602-0.848 \\
0.711 \pm 0.124\end{array}$ & $\begin{array}{c}0.122-0.354 \\
0.248 \pm 0.121 \\
0.171-0.829 \\
0.397 \pm 0.303\end{array}$ & $\begin{array}{l}0.122-0.200 \\
0.155 \pm 0.033 \\
0.179-0.612 \\
0.339 \pm 0.189\end{array}$ & $\begin{array}{l}0.209-0.968 \\
0.444 \pm 0.355 \\
0.213-0.354 \\
0.230 \pm 0.066\end{array}$ & $\begin{array}{c}0.294-0.364 \\
0.339 \pm 0.031 \\
0.114-0.966 \\
0.426 \pm 0.403\end{array}$ \\
\hline
\end{tabular}

$n$, number of samples; \pm , standard deviation.

Moreover, heavy metal bioaccumulation in the blood samples were found in the decreasing order of $\mathrm{Cr}>\mathrm{Zn}>\mathrm{Mn}>\mathrm{Ni}>\mathrm{Pb}>$ $\mathrm{Cu}>\mathrm{Cd}$ which was detected multi-fold higher than those reported by Jan et al. (2011) in Peshawar and Lower Dir in Pakistan, indicating large intake of metals through contaminated foods consumption, which clearly specifies the contribution of the selected food crops, milk and water on the metal composition of the human blood.

The mean bioaccumulations of $\mathrm{Cd}$ in the adults blood were $0.017 \pm 0.004, \quad 0.017 \pm 0.003, \quad 0.016 \pm 0.003, \quad 0.015 \pm 0.004$ and $0.019 \pm 0.003 \mathrm{mg} / \mathrm{L}$, while in the children blood they were $0.016 \pm$ $0.004,0.015 \pm 0.004,0.015 \pm 0.004,0.015 \pm 0.004$ and $0.017 \pm$ $0.003 \mathrm{mg} / \mathrm{L}$, in the five locations, namely Madyan, Fatehpur, Khwazakhela, Charbagh and Mingora, respectively (Table 2). The highest $\mathrm{Cd}$ bioaccumulation $(0.022 \mathrm{mg} / \mathrm{L})$ was recorded in the adult's blood at Mingora, which could be influenced by high ingestion of grains and vegetables in the area; however, its lowest bioaccumulation $(0.011 \mathrm{mg} / \mathrm{L})$ was detected in the adult's blood at Madyan and children blood at Fatehpur and Charbagh areas, respectively. Similarly, the mean $\mathrm{Cr}$ bioaccumulations in the adults blood were $0.643 \pm 0.010,0.649 \pm 0.005,0.666 \pm 0.003,0.675 \pm$ 0.003 and $0.685 \pm 0.001 \mathrm{mg} / \mathrm{L}$; while in the children blood they were $0.639 \pm 0.012, \quad 0.651 \pm 0.004, \quad 0.655 \pm 0.005, \quad 0.674 \pm 0.004$ and $0.680 \pm 0.003 \mathrm{mg} / \mathrm{L}$, in the same five locations, respectively (Table 2). The highest $\mathrm{Cr}$ bioaccumulation $(0.686 \mathrm{mg} / \mathrm{L})$ was recorded in the adult's blood at Mingora; while the lowest $(0.624 \mathrm{mg} / \mathrm{L})$ in the children blood at Madyan area. This high bioaccumulation of $\mathrm{Cr}$ in the blood may be due to high assimilation of water in the body. $\mathrm{Cu}$ and $\mathrm{Mn}$ bioaccumulations also show variation across the area and are given in Table 2. The mean Ni bioaccumulations in the adult's blood samples were $0.071 \pm 0.024,0.064 \pm 0.017,0.121 \pm 0.052,0.218 \pm$ 0.047 and $0.233 \pm 0.093 \mathrm{mg} / \mathrm{L}$, while in the children's blood samples they were $0.043 \pm 0.017,0.070 \pm 0.032,0.109 \pm 0.056,0.153 \pm 0.042$ and $0.172 \pm 0.143 \mathrm{mg} / \mathrm{L}$, in the same five locations, respectively (Table 2$)$. The highest Ni bioaccumulation $(0.386 \mathrm{mg} / \mathrm{L})$ was detected in the children blood at Mingora; while the lowest $(0.026 \mathrm{mg} / \mathrm{L})$ at Madyan area. This high bioaccumulation of $\mathrm{Ni}$ in the dweller's blood will be credited to high consumption of food crops particularly grains and fruits in the area. Whereas, $\mathrm{Pb}$ bioaccumulations in the adults blood samples were $0.025 \pm 0.019,0.034 \pm 0.001$, $0.102 \pm 0.004,0.052 \pm 0.029$ and $0.072 \pm 0.056 \mathrm{mg} / \mathrm{L}$; while in children blood its bioaccumulations were $0.015 \pm 0.013,0.062 \pm 0.020$, $0.026 \pm 0.021,0.056 \pm 0.025$ and $0.005 \pm 0.004 \mathrm{mg} / \mathrm{L}$, in the same five locations, respectively (Table 2). Its highest bioaccumulation $(0.107 \mathrm{mg} / \mathrm{L})$ was detected in the adults; while lowest $(0.002 \mathrm{mg} / \mathrm{L})$ in the children blood at Mingora. This high $\mathrm{Pb}$ bioaccumulation could be influenced by high intake rate of milk in children. Whereas, $\mathrm{Zn}$ is an essential trace metal, its distributions in the inhabitants blood are given in Table 2 .

It is obvious from the above results and the data presented in Table 2 and Fig. S1 (Supplementary material) that bioaccumulations of heavy metals in human blood were not uniform for both adults and children in the five locations. It is very likely due to high level of heavy metals variation in food chains (i.e., food crops, milk and water ingestion) which are the major pathways for exposure and sources of metals bioaccumulation in the adult's blood as compared to that of children.

\subsection{Heavy metal sources and their correlation with human blood}

To find out the major sources of heavy metal contamination for human blood, PCA (Varimax Kaiser Normalization) with three factors was applied for both adults and children blood samples 
Table 3

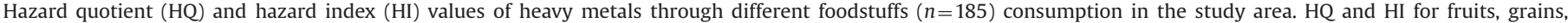
vegetables and water are based on the data given in our previous papers (Khan et al., 2013a, 2013b).

\begin{tabular}{|c|c|c|c|c|c|c|c|c|c|c|}
\hline Foodstuffs & Individual & Statistics & Cd & $\mathrm{Cr}$ & $\mathrm{Cu}$ & Mn & $\mathbf{N i}$ & $\mathbf{P b}$ & Zn & HI \\
\hline \multirow[t]{2}{*}{ Fruits $(n=20)$} & Adults & HQ & $6.60 \mathrm{E}-02$ & $3.60 \mathrm{E}-05$ & $1.50 \mathrm{E}-03$ & $8.40 \mathrm{E}-04$ & $3.50 \mathrm{E}-03$ & $1.80 \mathrm{E}-04$ & $1.10 \mathrm{E}-04$ & $7.22 \mathrm{E}-02$ \\
\hline & Children & HQ & $9.90 \mathrm{E}-02$ & $5.40 \mathrm{E}-05$ & $2.30 \mathrm{E}-03$ & $1.30 \mathrm{E}-03$ & $5.20 \mathrm{E}-03$ & $2.70 \mathrm{E}-04$ & $1.60 \mathrm{E}-04$ & $1.08 \mathrm{E}-01$ \\
\hline \multirow{2}{*}{ Grains $(n=20)$} & Adults & HQ & $7.90 \mathrm{E}-02$ & $3.00 \mathrm{E}-06$ & $2.20 \mathrm{E}-03$ & $1.60 \mathrm{E}-03$ & $5.50 \mathrm{E}-03$ & $2.10 \mathrm{E}-04$ & $2.80 \mathrm{E}-04$ & $8.88 \mathrm{E}-02$ \\
\hline & Children & $\mathrm{HQ}$ & $1.20 \mathrm{E}-01$ & $4.00 \mathrm{E}-06$ & $3.30 \mathrm{E}-03$ & $2.30 \mathrm{E}-03$ & $8.30 \mathrm{E}-03$ & $3.10 \mathrm{E}-04$ & $4.20 \mathrm{E}-04$ & $1.35 \mathrm{E}-01$ \\
\hline \multirow[t]{2}{*}{ Pulses $(n=25)$} & Adults & $\mathrm{HQ}$ & $5.80 \mathrm{E}-02$ & $2.70 \mathrm{E}-05$ & $3.60 \mathrm{E}-03$ & $1.70 \mathrm{E}-03$ & $1.40 \mathrm{E}-03$ & $2.20 \mathrm{E}-04$ & $3.10 \mathrm{E}-04$ & $6.53 \mathrm{E}-02$ \\
\hline & Children & $\mathrm{HQ}$ & $8.70 \mathrm{E}-02$ & $4.10 \mathrm{E}-05$ & $5.30 \mathrm{E}-03$ & $2.60 \mathrm{E}-03$ & $2.10 \mathrm{E}-03$ & $3.30 \mathrm{E}-04$ & $4.70 \mathrm{E}-04$ & $9.78 \mathrm{E}-02$ \\
\hline \multirow[t]{2}{*}{ Vegetables $(n=35)$} & Adults & HQ & $7.30 \mathrm{E}-02$ & $4.30 \mathrm{E}-05$ & $4.90 \mathrm{E}-04$ & $3.00 \mathrm{E}-04$ & $1.40 \mathrm{E}-03$ & $3.40 \mathrm{E}-05$ & $9.20 \mathrm{E}-05$ & $7.54 \mathrm{E}-02$ \\
\hline & Children & HQ & $1.10 \mathrm{E}-01$ & $6.50 \mathrm{E}-05$ & $7.40 \mathrm{E}-04$ & $4.50 \mathrm{E}-04$ & $2.20 \mathrm{E}-03$ & $5.10 \mathrm{E}-05$ & $1.40 \mathrm{E}-04$ & $1.14 \mathrm{E}-01$ \\
\hline \multirow[t]{2}{*}{ Fresh milk $(n=30)$} & Adults & HQ & $2.50 \mathrm{E}-01$ & $1.00 \mathrm{E}-03$ & $2.70 \mathrm{E}-02$ & $7.70 \mathrm{E}-03$ & $1.60 \mathrm{E}-02$ & $8.90 \mathrm{E}-03$ & $4.60 \mathrm{E}-03$ & $3.15 E-01$ \\
\hline & Children & HQ & $9.30 \mathrm{E}-01$ & $3.80 \mathrm{E}-03$ & $1.00 \mathrm{E}-01$ & $2.90 \mathrm{E}-02$ & $6.10 \mathrm{E}-02$ & $3.30 \mathrm{E}-02$ & $1.70 \mathrm{E}-02$ & $1.17 \mathrm{E}+00$ \\
\hline \multirow[t]{2}{*}{ Water $(n=55)$} & Adults & HQ & $6.70 \mathrm{E}-01$ & $8.30 \mathrm{E}-03$ & $6.80 \mathrm{E}-03$ & $2.70 \mathrm{E}-02$ & $8.60 \mathrm{E}-02$ & $1.80 \mathrm{E}-02$ & $2.00 \mathrm{E}-03$ & $8.18 \mathrm{E}-01$ \\
\hline & Children & HQ & $7.40 \mathrm{E}-01$ & $9.30 \mathrm{E}-03$ & $7.60 \mathrm{E}-03$ & $3.00 \mathrm{E}-02$ & $9.60 \mathrm{E}-02$ & $2.00 \mathrm{E}-02$ & $2.20 \mathrm{E}-03$ & $9.05 \mathrm{E}-01$ \\
\hline Foodstuffs & Population & HQ & $3.28 \mathrm{E}+00$ & $2.27 E-02$ & $1.61 E-01$ & $1.05 E-01$ & $2.89 E-01$ & $8.15 E-02$ & $2.78 \mathrm{E}-02$ & $3.97 E+00$ \\
\hline
\end{tabular}

$n$, number of samples; HI, hazard index (aggregate risks for multiple heavy metals).

a

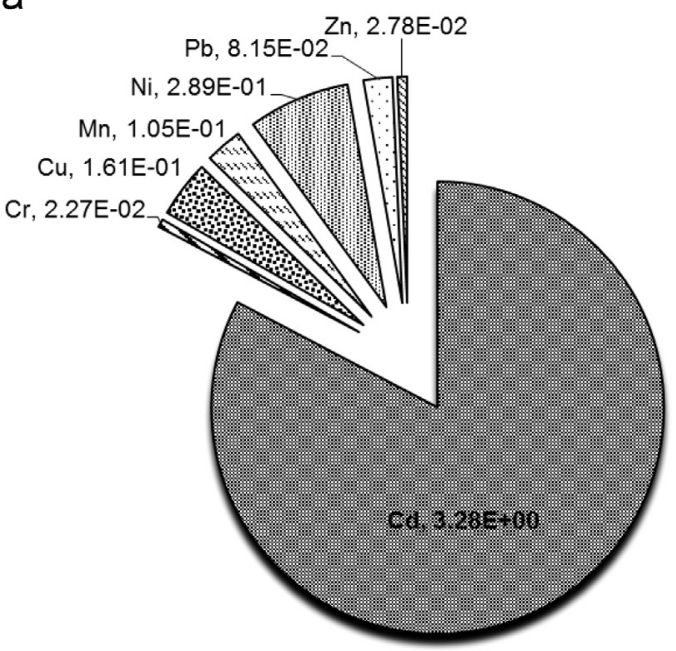

b

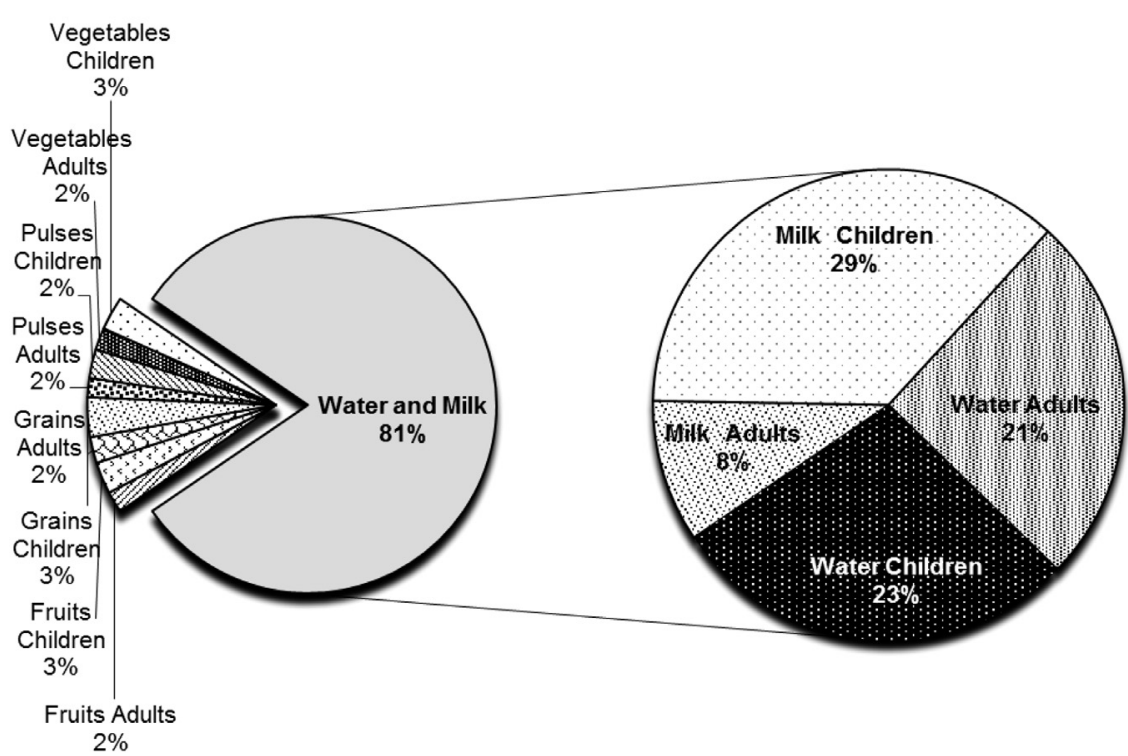

Fig. 3. Total metals hazard quotient (HQ) and hazard index (HI) values via foodstuffs consumption: (a) HQs contributions of heavy metals and (b) HI's contributions of different foodstuffs. 
separately. The results revealed 81.8 percent of the total cumulative variance for three factors in the adult's blood, in which Factor-1 contributed 33.7 percent to the total variance with a high loading on $\mathrm{Cr}(r=0.899), \mathrm{Ni}(r=0.896)$ and $\mathrm{Pb}(r=0.400)$ as shown in Table S3 (Supplementary material). Cr bioaccumulation in adults blood could be resulted from the high ingestion of water, Ni could be from the consumption of food crops particularly grains, fruits, vegetables and pulses, while $\mathrm{Pb}$ levels could be influenced by consumption of fruits and dairy product (milk). Factor-2 contributed 26.4 percent with a high loading on $\mathrm{Mn}(r=0.828), \mathrm{Cd}(r=0.779)$ and $\mathrm{Pb}$ $(r=0.501)$ as shown in Table S3 (Supplementary material). Mn and $\mathrm{Cd}$ bioaccumulation could be affected by ingestion of pulses, grains and vegetables, while $\mathrm{Pb}$ levels could be influenced by intake of dairy product (milk). Factor-3 contributed 21.8 percent with a high loading on $\mathrm{Zn}(r=0.971)$ and $\mathrm{Cu}(r=0.205)$ as shown in Table S3 (Supplementary material). Both $\mathrm{Mn}$ and $\mathrm{Cu}$ level in the adult's blood could be affected by consumption of grains, pulses and milk.

Similarly, for children the total cumulative variance for three factors was 71.4 percent, in which Factor-1 contributed 29.3 percent to the total variance with a high loading on $\mathrm{Cr}(r=$ 0.920), $\mathrm{Ni}(r=0.847)$ and $\mathrm{Cd}(r=220)$ as shown in Table S4 (Supplementary material). $\mathrm{Cd}$ and $\mathrm{Ni}$ bioaccumulation could be resulted from consumption of grains, fruits, vegetables and pulses, while $\mathrm{Cr}$ levels could be influenced by high intake rate of water and milk.

Factor-2 contributed 23.2 percent with a high loading on $\mathrm{Mn}(r=0.838)$ and $\mathrm{Cu}(r=0.448)$ and $\mathrm{Cd}(r=0.298)$, as shown in Table S4 (Supplementary material). Mn, Cu and Cd bioaccumulation could be affected by ingestion of food crops particularly pulses and grains.

Factor-3 contributed 18.9 percent with a high loading on $\mathrm{Pb}$ $(r=0.797), \mathrm{Cu}(r=0.425)$ as shown in Table S4 (Supplementary material). $\mathrm{Cu}$ bioaccumulation could be influenced by consumption of pulses and grains, while $\mathrm{Pb}$ levels could be affected by high intake rate of water and milk in the children food.

The results of Factor-1, Factor- 2 and Factor- 3 in both adults and children blood suggest that selected food crops, milk and water were the possible heavy metals contributors to human blood.

The PCA assumptions were further strengthened by Pearson correlation analysis, which provides valuable information about the heavy metal bioaccumulation and their respective pathways. The 2-tailed significance correlation results showed that heavy metals correlation between human blood (adults and children) and foodstuffs (i.e., crops, milk and water) were significantly strong, particularly for $\mathrm{Cr}, \mathrm{Cu}, \mathrm{Mn}, \mathrm{Ni}, \mathrm{Pb}$ and $\mathrm{Zn}$ as shown in Tables S5 and S6 (Supplementary material).

Briefly, for adults the blood $\mathrm{Cr}$ concentrations exhibited a strong significant positive correlation $(r=0.985)$ with $\mathrm{Cr}$ in pulses, $(r=0.972)$ with $\mathrm{Cr}$ in milk and $(r=0.952)$ with $\mathrm{Cr}$ in water; and a negative correlation $(r=-0.903)$ with $\mathrm{Cr}$ in fruits (Table S5, Supplementary material). Similarly, $\mathrm{Cu}$ contents in adults blood showed a significant positive correlation with the contents of $\mathrm{Cu}$ in pulses $(r=0.882)$. The blood Ni contents in adults showed a strong significant negative correlation $(r=-0.981)$ with the contents of $\mathrm{Ni}$ in grains (Table S5, Supplementary material).

Whereas, for children the $\mathrm{Cr}$ levels in blood also showed a strong significant positive correlation $(r=0.987)$ with $\mathrm{Cr}$ in pulses, $(r=0.965)$ with $\mathrm{Cr}$ in milk and $(r=0.905)$ with $\mathrm{Cr}$ in water; and a negative correlation $(r=-0.933)$ with $\mathrm{Cr}$ in fruits (Table S6, Supplementary material). Mn contents in children blood exhibited a positive correlation with the contents of $\mathrm{Mn}$ in water $(r=0.898)$ (Table S6, Supplementary material). Similarly, strong significant negative correlations $(r=-0.966)$ and $(r=-0.931)$ were identified between the blood $\mathrm{Ni}$ concentrations in children and $\mathrm{Ni}$ concentrations in grains and milk, respectively (Table S6, Supplementary material). The blood $\mathrm{Pb}$ concentrations in children also showed a strong significant negative correlation with $\mathrm{Pb}$ in milk $(r=-0.970)$. Whereas, $\mathrm{Zn}$ contents in the children blood exhibited a strong significant positive correlations $(r=0.984)$ and $(r=0.892)$ with the contents of $\mathrm{Zn}$ in water and fruits, respectively (Table S6, Supplementary material).

The positive correlation between heavy metal concentrations of human blood and foodstuffs suggest that the metals in human blood were transferred efficiently from the foodstuffs through ingestion, while negative correlation may be due to multiple interactions among heavy metals for bioaccumulation in the human blood.

\subsection{Risk assessments}

The accumulation of metals in the food crops, milk and water could have a direct impact on the health of local inhabitants. Therefore, the CDI, HQ and HI of metals via foodstuffs could be a concern to the local residents. The results revealed considerably high CDI through water and milk consumption for children followed by adults. Although all the CDI values were within safe limits, the highest value $(1.4 \mathrm{E}-02 \mathrm{mg} / \mathrm{kg}$-day) was recorded for children via $\mathrm{Cr}$ ingestion in water; whereas the lowest $(1.0 \mathrm{E}-$ $06 \mathrm{mg} / \mathrm{kg}$-day) for adults via $\mathrm{Pb}$ ingestion in pulses.

Moreover, the potential chronic risks for individual and multiple heavy metals ingestion via foodstuffs are summarized in Table 3. The potential chronic risks or $\mathrm{HQs}$ of $\mathrm{Cd}, \mathrm{Cr}, \mathrm{Cu}, \mathrm{Mn}, \mathrm{Ni}$, $\mathrm{Pb}$ and $\mathrm{Zn}$ for adults ranged from $5.8 \mathrm{E}-02$ to $6.7 \mathrm{E}-01,3.0 \mathrm{E}-06$ to $8.3 \mathrm{E}-03,4.9 \mathrm{E}-04$ to $2.7 \mathrm{E}-02,3.0 \mathrm{E}-04$ to $2.7 \mathrm{E}-02,1.4 \mathrm{E}-03$ to $8.6 \mathrm{E}-02,3.4 \mathrm{E}-05$ to $1.8 \mathrm{E}-02$ and $9.2 \mathrm{E}-05$ to $4.6 \mathrm{E}-03$, respectively; while those for children ranged from $8.7 \mathrm{E}-02$ to $9.3 \mathrm{E}-01$, $4.0 \mathrm{E}-06$ to $9.3 \mathrm{E}-03,7.4 \mathrm{E}-04$ to $1.0 \mathrm{E}-01,4.5 \mathrm{E}-04$ to $3.0 \mathrm{E}-02$, $2.1 \mathrm{E}-03$ to $9.6 \mathrm{E}-02,5.1 \mathrm{E}-05$ to $3.3 \mathrm{E}-02$ and $1.4 \mathrm{E}-04$ to $1.7 \mathrm{E}-$ 02 , respectively (Table 3 ). All the calculated HQs of individual heavy metals were less than 1 , suggesting that intake of a single metal through ingestion of food crops, milk and water did not pose a significant potential health hazard (Table 3 ). However, the aggregate HQs of every individual metals via different foodstuffs consumption were found in the decreasing order of $\mathrm{Cd}>\mathrm{Ni}>-$ $\mathrm{Cu}>\mathrm{Mn}>\mathrm{Pb}>\mathrm{Zn}>\mathrm{Cr}$. The highest $\mathrm{HQ}(3.28 \mathrm{E}+00)$ was recorded through $\mathrm{Cd}$ intake, while the lowest $(2.27 \mathrm{E}-02)$ through $\mathrm{Cr}$ (Fig. 3(a)). The high HQs could be influenced by the higher proportion of milk and water in the diet, which consequently increased the health risk indexes for both adults and children.

Further, the HI of seven heavy metals via foodstuffs was also calculated to assess the overall potential chronic effects posed by seven metals together (Table 3). The total HI of seven metals via food crops, milk and water ingestion was calculated as $3.97 \mathrm{E}+00$, $\mathrm{HI}>1$, suggesting a potential health risk in the area. Water and milk were found to be the major contributors ( 81 percent), to $\mathrm{HI}$; while fruits contribute 5 percent, grains 5 percent, pulses 4 percent and vegetables 5 percent, respectively (Fig. 3(b)).

\section{Conclusions}

It was concluded that heavy metal contaminations in the foodstuffs (food crops, milk and water) and human blood were decreasing in the order of $\mathrm{Mn}>\mathrm{Cr}>\mathrm{Cu}>\mathrm{Zn}>\mathrm{Ni}>\mathrm{Cd}>\mathrm{Pb}$ and $\mathrm{Cr}>\mathrm{Zn}>\mathrm{Mn}>\mathrm{Ni}>\mathrm{Pb}>\mathrm{Cu}>\mathrm{Cd}$, respectively. The concentrations of $\mathrm{Cd}, \mathrm{Cr}, \mathrm{Ni}$ and $\mathrm{Pb}$ in the foodstuffs were detected significantly higher than their safe limits, which considerably increased the levels of heavy metals in the adult's blood as compared to that of children. Further, principal component analysis demonstrated that food crops, milk and water were the possible sources of contamination/bioaccumulation in human blood, while correlation analysis revealed that the heavy metals 
concentrations in foodstuffs and blood were significantly correlated, particularly for $\mathrm{Cr}, \mathrm{Cu}, \mathrm{Mn}, \mathrm{Ni}, \mathrm{Pb}$ and $\mathrm{Zn}$, indicating that these food chains (i.e., food crops, milk and water ingestion) may be the major pathways for exposure and sources of metals bioaccumulation in human blood. Moreover, risk assessments for individual metals were within safe limits, except for $\mathrm{Cd}$, showing high level of $\mathrm{HQ}(\mathrm{HQ} \geq 3.28 \mathrm{E}+00)$. Whereas, the aggregate $\mathrm{HI}$ for multiple heavy metals via foodstuffs was calculated as $3.97 \mathrm{E}+00$ $(\mathrm{HI}>1)$, which may pose a potential health risk for the consumers. Water and milk were considered as the major contributors (81 percent) to $\mathrm{HI}$; while fruits contributed 5 percent, grains 5 percent, pulses 4 percent and vegetables 5 percent, respectively. Therefore, based on our findings we strongly advise the environmental protection authority to monitor the heavy metal concentrations in foodstuffs and increase awareness among the population regarding potential health risks for various exposures to heavy metals.

\section{Acknowledgments}

This study was supported by the Key Project of the Chinese Academy of Sciences under Grant no. KZZD-EW-TZ-12. The financial assistance for this research work was provided by the Chinese Academy of Sciences (CAS), China and The World Academy of Sciences (TWAS), Italy under FR number 3240255020, in the form of one year Postgraduate Fellowship to the first author.

\section{Appendix A. Supplementary information}

Supplementary data associated with this article can be found in the online version at http://dx.doi.org/10.1016/j.ecoenv.2014.05.014.

\section{References}

Ali, S.M., Malik, R.N., 2011. Spatial distribution of metals in top soils of Islamabad City, Pakistan. Environ. Monit. Assess. 172, 1-16.

Amin, N., Husain, A., Lamaze, S., Begum, S., 2013. Accumulation of heavy metals in edible parts of vegetables irrigated with waste water and their daily intake to adults and children, district Mardan, Pakistan. Food Chem. 136, 1515-1523.

Bermudez, G.M., Jasan, R., Plá, R., Pignata, M.L., 2011. Heavy metal and trace element concentrations in wheat grains: assessment of potential noncarcinogenic health hazard through their consumption. J. Hazard. Mater. 193, 264-271.

Bocca, B., Madeddu, R., Asara, Y., Tolu, P., Marchal, J.A., Forte, G., 2011. Assessment of reference ranges for blood $\mathrm{Cu}, \mathrm{Mn}$, Se and $\mathrm{Zn}$ in a selected Italian population. J. Trace Elem. Med. Biol. 25, 19-26.

Cao, H., Chen, J., Zhang, J., Zhang, H., Qiao, L., Men, Y., 2010. Heavy metals in rice and garden vegetables and their potential health risks to inhabitants in the vicinity of an industrial zone in Jiangsu, China. J. Environ. Sci. (China) 22, 1792-1799.

Chary, N.S., Kamala, C.T., Suman Raj, D.S., 2008. Assessing risk of heavy metals from consuming food grown on sewage irrigated soils and food chain transfer. Ecotoxicol. Environ. Saf. 69, 513-524.

Donaldson, S.G., Van Potsdam, J., Tikhonov, C., Feeley, M., Armstrong, B., Ayotte, P., Boucher, O., Bowers, W., Chan, L., Dallaire, F., Dallaire, R., Dewailly, É., Edwards, J. Egeland, G.M., Fontaine, J., Furgal, C., Leech, T., Loring, E., Muckle, G., Nancarrow, T., Pereg, D., Plusquellec, P., Potyrala, M., Receveur, O., Shearer, R.G., 2010. Environmental contaminants and human health in the Canadian Arctic. Sci. Total Environ. 408, 5165-5234.

Er, C., Senkal, B.F., Yaman, M., 2013. Determination of lead in milk and yoghurt samples by solid phase extraction using a novel aminothioazole-polymeric resin. Food Chem. 137, 55-61.
Farid, S.M., Enani, M.A., Wajid, S.A., 2004. Determination of trace elements in cow's milk in Saudi Arabia. J. King Abdulaziz Univ.: Eng. Sci. 15, 131-140.

Fischer, A.B., Georgieva, R., Nikolova, V., Halkova, J., Bainova, A., Hristeva, V., Penkov, D., Alandjiisk, D., 2003. Health risk for children from lead and cadmium near a nonferrous smelter in Bulgaria. Int. J. Hyg. Environ. Health 206, 25-38.

Fytianos, K., Katsianis, G., Triantafyllou, P., Zachariadis, G., 2001. Accumulation of heavy metals in vegetables grown in an industrial area in relation to soil. Bull. Environ. Contam. Toxicol. 67, 423-430.

Hu, W., Huang, B., Chen, W., Zhao, Y., Jiao, W., 2013. Accumulation and health risk of heavy metals in a plot-scale vegetable production system in a peri-urban vegetable farm near Nanjing, China. Ecotoxicol. Environ. Saf. 98, 303-309.

Huang, M., Zhou, S., Sun, B., Zhao, Q., 2008. Heavy metals in wheat grain: assessment of potential health risk for inhabitants in Kunshan, China. Sci. Total Environ. 405, 54-61.

Jan, F.A., Ishaq, M., Khan, S., Ihsanullah, I., Ahmad, I., Shakirullah, M., 2010. A comparative study of human health risks via consumption of food crops grown on wastewater irrigated soil (Peshawar) and relatively clean water irrigated soil (lower Dir). J. Hazard. Mater. 179, 612-621.

Jan, F.A., Ishaq, M., Khan, S., Shakirullah, M., Asim, S.M., Ahmad, I., Mabiid, F., 2011. Bioaccumulation of metals in human blood in industrially contaminated area. J. Environ. Sci. (China) 23, 2069-2077.

Kavcar, P., Sofuoglu, A., Sofuoglu, S.C., 2009. A health risk assessment for exposure to trace metals via drinking water ingestion pathway. Int. J. Hyg. Environ. Health 212, 216-227.

Khan, K., Lu, Y., Khan, H., Ishtiaq, M., Khan, S., Waqas, M., Wei, L., Wang, T., 2013a. Heavy metals in agricultural soils and crops and their health risks in Swa District, northern Pakistan. Food Chem. Toxicol. 58, 449-458.

Khan, K., Lu, Y., Khan, H., Zakir, S., Ihsanullah, Khan, S., Khan, A.A., Wei, L., Wang, T., 2013b. Health risks associated with heavy metals in the drinking water of Swat, northern Pakistan. J. Environ. Sci. (China) 25 (10), 1-10.

Khan, M.U., Malik, R.N., Muhammad, S., 2013. Human health risk from heavy metal via food crops consumption with wastewater irrigation practices in Pakistan. Chemosphere 93, 2230-2238.

Khan, S., Cao, Q., Zheng, Y.M., Huang, Y.Z, Zhu, Y.G., 2008. Health risks of heavy metals in contaminated soils and food crops irrigated with wastewater in Beijing China. Environ. Pollut. 152, 686-692.

Khan, S., Rehman, S., Khan, A.Z., Khan, A., Shah, M.T., 2010. Soil and vegetables enrichment with heavy metals from geological sources in Gilgit, northern Pakistan. Ecotoxicol. Environ. Saf. 73, 1820-1827.

Mijal, R.S., Holzman, C.B., 2010. Blood cadmium levels in women of child bearing age vary by race/ethnicity. Environ. Res. 110, 505-512.

Muhammad, S., Shah, M.T., Khan, S., 2011. Health risk assessment of heavy metals and their source apportionment in drinking water of Kohistan region, northern Pakistan. Microchem. J. 98, 334-343.

Pasha, Q., Malik, S.A., Shaheen, N., Shah, M.H., 2010. Investigation of trace metals in the blood plasma and scalp hair of gastrointestinal cancer patients in comparison with controls. Clin. Chim. Acta 411, 531-539.

Qasim, M., Hubacek, K., Termansen, M., Khan, A., 2011. Spatial and temporal dynamics of land use pattern in District Swat, Hindu Kush Himalayan region of Pakistan. Appl. Geogr. 31, 820-828.

Rahman, A.U., Khan, A.N., 2011. Analysis of flood causes and associated socioeconomic damages in the Hindu Kush region. Nat. Hazards 59, 1239-1260.

Rahman, M.A., Rahman, M.M., Reichman, S.M., Lim, R.P., Naidu, R., 2014. Heavy metals in Australian grown and imported rice and vegetables on sale in Australia: health hazard. Ecotoxicol. Environ. Saf. 100, 53-60.

Sekomo, C.B., Nkurang, E., Rousseau, D.P., Lens, P.N., 2011. Fate of heavy metals in an urban natural wetland: the Nyabugogo Swamp (Rwanda). Water Air Soil Pollut. 214, 321-333.

Shah, M.T., Ara, J., Muhammad, S., Khan, S., Tariq, S., 2012. Health risk assessment via surface water and sub-surface water consumption in the mafic and ultramafic terrain, Mohmand agency, northern Pakistan. J. Geochem. Explor. $118,60-67$.

Singh, A., Sharma, R.K., Agrawal, M., Marshall, F.M., 2010. Health risk assessment of heavy metals via dietary intake of foodstuffs from the wastewater irrigated site of a dry tropical area of India. Food Chem. Toxicol. 48, 611-619.

US EPA, 2005. Guidelines for Carcinogen Risk Assessment. Risk Assessment Forum. United States Environmental Protection Agency, Washington, DC (EPA/630/P03/001F).

US EPA, 2011. Exposure Factors Handbook. United States Environmental Protection Agency, Washington, DC (EPA/600/R-09/052F).

Zhao, H., Xia, B., Fan, C., Zhao, P., Shen, S., 2012. Human health risk from soil heavy metal contamination under different land uses near Dabaoshan Mine, Southern China. Sci. Total Environ. 417-418, 45-54. 